\title{
A study on relationship between information technology facilities and performance of banking industry
}

\author{
M. Khodaei Valahzaghard ${ }^{a^{*}}$ and A. Shakourloo ${ }^{\mathrm{b}}$
}

${ }^{a}$ Assist. Prof. \& Faculty Member, Department of Accounting, School of Management and Human Sciences, Tehran North Branch, Islamic Azad University (IAU), Tehran, Iran

${ }^{b}$ M.Sc. Student, Department of management, School of Management and Human Sciences, Tehran north branch, Islamic Azad University (IAU), Iran

C H R O N I C L E

Article history:

Received October 28, 2012

Received in revised format

20 January 2013

Accepted 25 January 2013

Available online

February 22013

Keywords:

Information technology

Banking industry

Performance measurement \begin{abstract}
A B S T R A C T
The recent advances on information technology have made tremendous change on traditional banking. These days, people do not carry cash and prefer to use electronic devices such as point of sale system (POS) or PIN entry devices (PinPad) to do desirable transactions. These technologies could facilitate e-business and increase profitability in various industries including banking sector. The purpose of this paper is to investigate the effect of five new products namely ATM, POS Machines, PinPad machines, online and swift branches on banking performance indicators including return on assets (ROA), return on equities (ROE) and operating investment return (OIR). We use the information of 19 private and governmental banks, which were active in Iran over the period of 2005-2010. The study uses linear regression analysis as well as VAR technique to study the effects of the independent variables on bank performance indicators. The results indicate that while there are some weak and positive relationships between three technology indicators including POS, PinPad and online businesses and ROA as well as ROE, there is relatively strong and positive relationship between these three independent variables and OIR. In addition, while the results of VAR analysis have shown that any reduction on PinPad will reduce OIR but this reduction will disappear after approximately four periods.
\end{abstract}

\section{Introduction}

The recent advances on technology have contributed on banking industry, significantly (Arthur, 1989; Hitt, \& Brynjolfsson, 1996; Lucas, 1999). People do not need to go bank branches since they can take banking transaction using the easy access technology achievements (Porter, 1980, 1985). These days, people do carry cash and prefer to use electronic devices such as point of sale system (POS) or PIN entry devices (PinPad) to make desirable transactions. These technologies could facilitate e-business and increase profitability in various industries including banking sector. Beccalli (2007) investigated whether investment on information technology (IT) including hardware, software and other IT services could have any impact on the performance of banks. He concluded that investment in IT

Corresponding author. Tel: +98-912-3443139

E-mail: m_khodaei@iau-tnb.ac.ir (M. Khodaei Valahzaghard)

(c) 2013 Growing Science Ltd. All rights reserved. doi: 10.5267/j.msl.2013.02.003 
services from external providers such as consulting services, implementation services, training and education, support services positively impact on accounting profits and profit efficiency. According to Bharadwaj et al. (1999), in spite of increasing anecdotal evidence that IT assets could contribute to company performance and future growth potential of companies, the empirical results relating IT investments to firm performance measures were reported to be equivocal. Nevertheless, some studies have relied exclusively on accounting-based measures of firm performance, which largely might ignore IT's contribution to performance dimensions such as strategic flexibility and intangible value. Bharadwaj et al. (1999) implemented Tobin's q, a financial market-based measure of firm performance and investigated the relationship between IT investments and firm $\mathrm{q}$ values, after controlling. They concluded that the inclusion of the IT cost variable in the model could increase the variance explained in q significantly. According to Chen et al. (2006), the increasing IT implementation has resulted in a necessity for assessing the productivity influences of IT. They developed a data envelopment analysis (DEA) to evaluate the effect of IT on multiple stages along with information on how to distribute the IT-related resources. They reported that the model could be treated as a parametric linear program and they showed that if there were only one intermediate measure, then the proposed DEA model would become a linear program.

Irwin et al. (1998) examined the relationship between the acquisition of technological innovations and organizational performance using the framework of firm resource-based theory. They reported a positive and significant relationship between the acquisition of medical technological innovations and hospital financial performance. Kudyba and Diwan (2002) analyzed firm-level investment in IT and corresponding productivity through the implementation of a production function over the period 1995- 1997. They reported that investment in IT could enhance productivity over the period in question and illustrated increasing returns over time. Lin (2007) investigated whether the firm IT capability of a firm could create economic value and competitive advantage. He examined IT capability directly using a cross-sectional sample of 155 banking firms, Lin investigated the main and interactive impacts of IT capability and human capital investment on five firm-performance measures. He reported that both IT capability and human capital investment could contribute directly to the overall value-creation performance of banking firms. In addition, a firm's IT capability should be seen as an integral tool for creating economic value instead of a business infrastructure, which could make business operations efficient.

Lin and Hsieh (2007), in another assignment, investigated the impact of technology readiness on satisfaction and behavioral intentions toward self-service technologies. Wu and Wang (2007) analyzed how business units transform resources into performance, and proposes, which dynamic capabilities serve as a link for transforming internal and external resources first into firm competitiveness, and then into financial performance. They concluded that technological-based firms could transform their resources into profit via dynamic capabilities and competitiveness.

\section{The proposed method}

The purpose of this paper is to investigate the effect of five new products namely ATM, POS Machines, PinPad machines, online and swift branches on banking performance indicators including return on assets (ROA), return on equities (ROE) and operating investment return (OIR). The study uses linear regression analysis as well as VAR technique to study the effects of the independent variables on bank performance indicators. We use the information of 19 private and governmental banks, which were active in Iran over the period of 2005-2010.

Table 1 shows some basis statistics associated with the proposed study of this paper. We first discuss some basic statistics associated with the data including mean, standard deviation, minimum and maximum of the data. As we can observe from the results of Table 1, the return of assets (ROA) maintains a mean of 0.0139 with standard deviation of 0.01652 . The minimum and maximum of information are -0.05 and 0.08 , respectively. 
Table 1

Basic statistics associated with the data

\begin{tabular}{ccccc}
\hline Variables & Maximum & Minimum & Mean & Std. Dev. \\
\hline ROA & 0.08 & -0.05 & 0.0139 & 0.01652 \\
ROE & 3.12 & -0.13 & 0.1932 & 0.36986 \\
OIR & 9185214 & 0 & 154925 & 1164074 \\
NB & 3277 & 1 & 920.55 & 1059.79 \\
ONLINEB & 3415 & 0 & 798.2 & 970.22 \\
SWIEFTB & 151 & 0 & 24.9 & 33.88 \\
POSB & 336467 & 0 & 35061.3 & 62532.7 \\
PINPADB & 13918 & 0 & 1308.3 & 2216.67 \\
ATM & 59356 & 0 & 1156.97 & 5561.16 \\
\hline
\end{tabular}

This means some banks reported loss in their statements and some others maintained profit. In terms of return on equities, we have some similar circumstances and some of the banks reported loss while the others reported profit. In terms of electronic transaction, the number of automated teller machine (ATM) maintained a maximum of 59356 while it holds mean and standard deviation of 1156.97 and 5561.16, respectively. In addition, the maximum number of PinPad machine (PINPADB) was reported as 13918 while it maintained a mean and standard deviation of 1308.3 and 2216.67, respectively. The maximum number of banking Pos (POSB), Swift and Online transactions were reported as 336467, 151 and 3415, respectively.

\section{The results}

In this section, we present some detailed results of implementing regression analysis where dependent variables are financial performances such return of assets or return of equities and independent variables include information technology features such as ATM, POSs, Pin Pad machines, etc.

\subsection{The relationship between return of assets and information technology components}

The first hypotheses of this survey considers the relationship between ROA and five other independent variables as follows,

H0. ATMs, have no positive relationship with banks ROA

$\mathrm{HO}_{2}$.PINPAD, have no positive relationship with banks $R O A$

$\mathrm{HO}_{3}$.POSMACHINEs, have no positive relationship with banks ROA

$\mathrm{H0}_{4}$.SWIEFT BRANCHESs, have no positive relationship with banks ROA

$\mathrm{HO}_{5}$. ONLINEBRANCHEs, have no positive relationship with banks ROA

We have used regression analysis between ROA and IT components and Eq. (2) summarizes the results of our regression analysis.

$$
\begin{aligned}
R O A= & 0.009 A T M+0.163 P O S+0.05 P i n P a d-0.069 S \text { wieft }-0.466 \text { Online } \\
& R^{2}=0.186, F=4.94
\end{aligned}
$$

As we can observe from the results of Eq. (2), there are positive relationships between the first three independent variables of the proposed study and return of assets. R-Square is equal to 0.186, which means the regression describes approximately $19 \%$ of the changes on ROA. Therefore, the first three null hypotheses between return of asset from one side and ATM, PINPAD and Pos Machines are rejected. 
3.2 The relationship between return of equities and information technology components

The second hypotheses of this survey considers the relationship between ROA and five other independent variables as follows,

$H_{1}$.ATMs, have no positive relationship with banks ROE

$\mathrm{HO}_{2}$.PINPAD, have no positive relationship with banks ROE

$\mathrm{HO}_{3}$.POSMACHINEs, have no positive relationship with banks ROE

$\mathrm{HO}_{4 .}$ SWIEFT BRANCHESs, have no positive relationship with banks ROE

$\mathrm{HO}_{5}$.ONLINEBRANCHEs, have no positive relationship with banks ROE

We have used regression analysis between ROE and IT components and Eq. (2) summarizes the results of our regression analysis.

$$
\begin{aligned}
R O E= & 0.004 A T M+0.156 P O S+0.024 \text { PinPad }-0.070 \text { Swieft }-0.374 \text { Online } \\
& R^{2}=0.086, F=2.03
\end{aligned}
$$

The results of Eq. (3) are similar to what we have found earlier and we can conclude that there are weaker and positive relationships between the first three independent variables of the proposed study and return of equities. R-Square is equal to 0.086, which means the regression describes approximately $8.9 \%$ of the changes on ROE. Therefore, the first three null hypotheses between return of asset from one side and ATM, PinPad and Pos Machines are rejected.

\subsection{The relationship between operating income revenue and information technology components}

The second hypotheses of this survey considers the relationship between operating income revenue (OIR) and five other independent variables as follows,

$\mathrm{HO}_{1}$.ATMs, have no positive relationship with banks OIR

$\mathrm{HO}_{2}$.PINPAD, have no positive relationship with banks OIR

$\mathrm{HO}_{3}$.POSMACHINEs, have no positive relationship with banks OIR

$\mathrm{HO}_{4 .}$ SWIEFT BRANCHESs, have no positive relationship with banks OIR

H0 $_{5}$.ONLINEBRANCHEs, have no positive relationship with banks OIR

We have used regression analysis between OIR and IT components and Eq. (3) summarizes the results of our regression analysis.

$$
\begin{aligned}
\text { OIR }= & 0.730 A T M+0.005 P O S+0.065 \text { PinPad }-0.041 \text { Swieft }-0.139 \text { Online } \\
& R^{2}=0.548, F=26.217
\end{aligned}
$$

The results of Eq. (3) indicate that there are some positive and meaningful relationships between the first three independent variables of the proposed study and OIR. R-Square is equal to 0.548, which means the regression describes approximately $54.8 \%$ of the changes on OIR. Therefore, the first three null hypotheses between OIR from one side and ATM, PINPAD and Pos Machines are rejected. 
In summary, we have seen some relatively meaningful but weak relationships between three independent variables of ATM, POS and PinPad and ROA and ROE as dependent variables. However, there are relatively strong relationships between OIR and other three independent variables of ATM, POS and PinPad. In addition, none of three regression models has found any meaningful relationship between swift and online transactions and ROA, ROE or OIR. Since three variables of ATM, POS and PinPad maintain the highest impact on OIR, we have decided to perform a VAR analysis to investigate the effects of OIR. Fig. 1 shows the response of ATM to OIR as well as OIR to ATM.
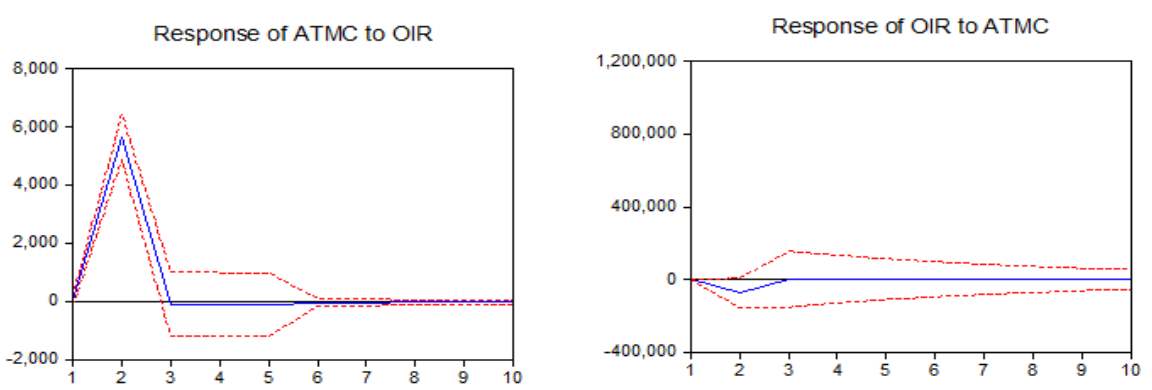

Fig. 1. The impacts of ATM to OIR and OIR on ATM

In addition, Fig. 2 demonstrates the impacts of PinPad on OIR as well as the impacts of OIR on PinPad.
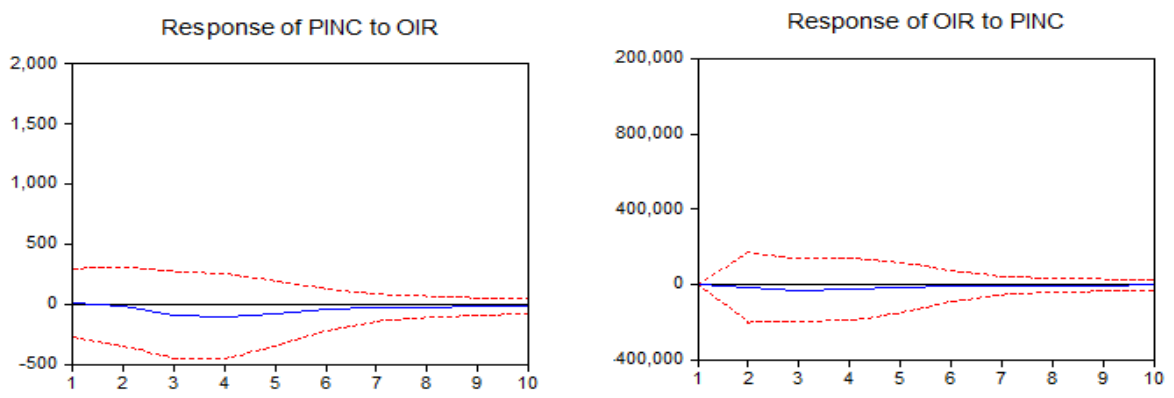

Fig. 2. The impacts of PinPad to OIR and OIR on PinPad Finally, Fig. 3 present the impacts of POS on OIR and OIR on POS.
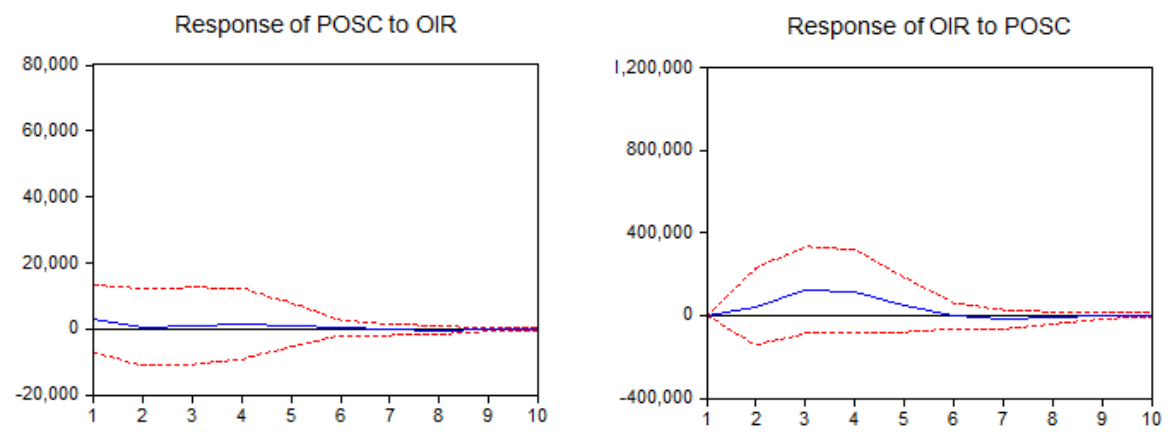

Fig. 3. The impacts of POS to OIR and OIR on POS 
The results of Fig. 1, Fig. 2 and Fig. 3 show that any reduction on PinPad will reduce OIR but this reduction will disappear after approximately four periods.

\section{Conclusion}

Banking industry has been one of the most important components of any economy in the world. Banking industry helps people keep their saving on one site and create opportunities for industry owners to do financing. Therefore, an efficient and profitable banking sector could contribute to overall economy. In this paper, we have discussed how recent development on technology could increase banks’ profitability and effectiveness by strongly influencing OIR ratios.

\section{References}

Arthur, W. B. (1989). Competing technologies, increasing returns, and lock-in by historical events. The economic journal, 99(394), 116-131.

Beccalli, E. (2007). Does IT investment improve bank performance? Evidence from Europe. Journal of banking \& finance, 31(7), 2205-2230.

Bharadwaj, A. S., Bharadwaj, S. G., \& Konsynski, B. R. (1999). Information technology effects on firm performance as measured by Tobin's q. Management science, 45(7), 1008-1024.

Chen, Y., Liang, L., Yang, F., \& Zhu, J. (2006). Evaluation of information technology investment: a data envelopment analysis approach. Computers \& Operations Research, 33(5), 1368-1379.

Hitt, L. M., \& Brynjolfsson, E. (1996). Productivity, Business Profitability, and Consumer Surplus: Three Different Measures of. MIS quarterly, 20(2), 121-143.

Irwin, J. G., Hoffman, J. J., \& Lamont, B. T. (1998). The effect of the acquisition of technological innovations on organizational performance: A resource-based view. Journal of Engineering and Technology Management, 15(1), 25-54.

Kudyba, S., \& Diwan, R. (2002). The impact of information technology on US industry. Japan and the World Economy, 14(3), 321-333.

Lin, B. W. (2007). Information technology capability and value creation: Evidence from the US banking industry. Technology in Society, 29(1), 93-106.

Lin, J. S. C., \& Hsieh, P. L. (2007). The influence of technology readiness on satisfaction and behavioral intentions toward self-service technologies. Computers in Human Behavior, 23(3), 1597-1615.

Lucas Jr, H. C. (1999). Information technology and the productivity paradox: Assessing the value of investing in IT. Oxford University Press, USA.

Michael, S. C. (2007). Can information technology enable profitable diversification? An empirical examination. Journal of Engineering and Technology Management, 24(3), 167-185.

Porter, M.E. (1980). Competitive Strategy: Techniques for Analyzing Industries and Competitors. The Free Press, New York.

Porter, M.E. (1985). Competitive Advantage. The Free Press, New York.

Wu, L. Y., \& Wang, C. J. (2007). Transforming resources to improve performance of technologybased firms: A Taiwanese Empirical Study. Journal of Engineering and Technology Management, 24(3), 251-261. 